\title{
3. The 1869 Aborigines Protection Act: Vernacular ethnography and the governance of Aboriginal subjects
}

\author{
Leigh Boucher
}

In 1864, Theo Sumner, Vice-President of the Victorian Central Board for the Protection of Aborigines (CBPA) noted with some frustration that members of the Board worked 'under severe disadvantages at present [and] many of their schemes are thwarted'. ${ }^{1}$ According to his annual report, the instantiation of the Board at the request of the Governor after an 1858 Select Committee represented a chance to 'attend to the wants of the blacks' who were clearly struggling for survival in the wake of the violent transformations of settler colonial dispossession and its continuing effects. ${ }^{2}$ However, Sumner argued the CBPA occupied an untenably ambiguous position within the legislative and institutional frameworks of colonial governance. This was not simply an appeal for more financial support; the CBPA's projects of protection, Sumner argued, were 'thwarted and some have been abandoned solely for the want of power to give effect to them'. The CBPA asked for legislative authority to intervene into the lives of Aboriginal people, their relationships with the colonial state and their engagements with colonial employers. Sumner regretted that whilst 'a very short Bill would contain all that is necessary to enable them to extend their labours ... their urgent solicitations for some amendment of the laws affecting the blacks have not yet received attention'. ${ }^{3}$ To be fair, endemic government instability in the 1860s in Victoria meant that many reforming projects struggled to negotiate the game of musical ministers that unfolded in colonial parliament. Finally, however, in 1869 the CBPA's desire for more power was fulfilled. As what would become the Aborigines Protection Act 1869 (Vic) made smooth progress between the upper and lower houses of colonial parliament, legislators suggested this was 'the performance of a very tardy act of justice to a long neglected portion of the human family ... whose lands we have to a large extent usurped'. Sumner must have been pleased to finally hear parliamentarians acknowledge that the 'enlargement ... of the powers of the Board', would enable the CBPA and its

\footnotetext{
1 Many thanks to Jordy Silverstein and Kyle Harvey for research assistance on this article, to Kate Fullagar for her thoughtful comments, and to Lynette Russell for her ongoing conversations about the project from which it is drawn.

Fourth Report of the Central Board Appointed to Watch Over the Interests of the Aborigines in the Colony, John Ferres, Government Printer, Melbourne, 1864: 13 (henceforth, CBPA Annual Report).

2 First CBPA Annual Report (1861): 2.

3 Fourth CBPA Annual Report (1864): 13.
} 
guardians to 'protect the members of this race' because previously 'they [had] not the power to protect the interests of the aborigines in such a way as to be of service to them'. ${ }^{4}$

The 1869 Act seems, in many ways, to represent the legislative embodiment of a 60-year-old humanitarian tradition long nourished by differing branches and styles of evangelical Protestantism. This tradition had criticised the impact of what James Belich terms the settler revolution in the British world almost as soon as it took shape in the 1780s. ${ }^{5}$ Indeed, in its preface to a reprint of the 1837 Westminster inquiry into the treatment of 'native inhabitants ... of British Settlements', the Aborigines Protection Society in Britain called for 'immediate legislative interference'. They reminded the 'British public' that the committee had called for both 'protection' from settler violence and more fulsome support to ensure that Indigenous peoples could be led 'to the peaceful and voluntary reception of the Christian religion'. ${ }^{6}$ The granting of self-government in the intervening years across the settler periphery, however, meant that after the 1850s any humanitarian legal intervention would have to come from colonial legislatures rather than Westminster. ${ }^{7}$

The successful campaign of the Victorian CBPA for a 'Protection Act' seemed to grant humanitarians and missionaries in colonial Victoria the kinds of authority and power that Michael Christie suggests their British forebears had so desperately wanted but had been unable to secure. ${ }^{8}$ Ironically, the very settlers that humanitarians in Britain condemned produced the kind of legislative intervention they had sought. The echoes of humanitarian thought reverberated through the discursive landscape that surrounded the Act; an evangelical vocabulary that argued for 'protection and justice' for neglected members of the 'family of man' often framed public discussion. However, it was also one of the most far-reaching intrusions into the lives and liberties of Indigenous peoples yet seen in the nineteenth century. The Board would now be able to employ the mechanisms of the colonial state to control where Aboriginal adults lived, where their children went to school, what happened to any income they earned, and even the clothes they wore - simply by virtue of their legal status as an 'Aborigine'. Whilst evangelical claims for justice and compassion

\footnotetext{
4 Victorian Parliamentary Debates: Legislative Council and Legislative Assembly, Government Printer, Melbourne, 1869: 1726-1727, 1808 (henceforth, VPD).

5 James Belich, Replenishing the Earth: The Settler Revolution and the Rise of the Anglo-world, Oxford University Press, Oxford, 2009: 21-23.

6 Report of the Select Committee on Aboriginal Tribes (British Settlements): Reprinted, with comments by the 'Aborigines Protection Society', William Ball, London, 1837: 4, 7, 15.

7 Although this concern did have an impact on how colonial constitutions would be written and, indeed, the treatment of Indigenous peoples was a snag for campaigns for self-government in Western Australia. Ann Curthoys, 'Taking liberty: towards a new political historiography of settler self-government and political activism', in Kate Fullagar (ed.), The Atlantic World in the Antipodes, Cambridge Scholars Press, Cambridge, 2008: 237-255.

8 Michael Christie, Aborigines in Colonial Victoria, 1835-1886, Sydney University Press, Sydney, 1979: 177.
} 
provided a powerful justification for this kind of intervention, they also granted the system of guardians, reserves and missions that had taken shape under the CBPA's gaze in the 1860s an exceptional form of legislative authority. As the Minister for Justice described to his fellow legislators, the Bill was 'intended to provide for the protection and management of the aboriginal natives of Victoria' and he predicted the legislation would enable 'the board to watch over the adult aboriginals throughout the colony' because the CBPA would now 'act in loco parentis to the aborigines'. ${ }^{9}$

In some ways, then, this piece of legislation exemplified the kind of racialising strategies that scholars like Ann Laura Stoler suggest buttressed colonial authority. This seems like a moment in which one of the 'powerful but false premises' of colonialism made its harder-edged logics more apparent; as Stoler argues, 'colonial control was predicated on constructing categories' that functioned to make racial difference seem 'self evident' ${ }^{10}$ In Victoria in 1869, Aboriginal people became governable subjects in a newly powerful assembly of legislation, bureaucracy, knowledge and practice. Perhaps, though, we need a more careful account of how this transformation occurred. Indeed, given the long history of ambivalent (if not hostile) engagements between colonial authorities and evangelical practices, how did the CPBA and then the Act suture together the long-standing discourse of evangelical protection with emerging ideas about the rights and entitlements of colonial subjecthood? As Andrew Porter notes, 'imperial control, colonial societies and the missionary movement intertwined in divergent and ambiguous ways' across the empire. ${ }^{11}$ What kind of entanglement made such a powerful set of restrictions possible?

\section{Historians, race and the 1869 Protection Act}

Interestingly, of the two major pieces of legislation that took the 'Aborigine' as their direct object in colonial Victoria (the 1869 so-called 'Protection Act' and Aborigines Protection Act 1886 (Vic) or 'Half-Caste Act'), the latter has secured far more attention from historians. Perhaps because the 1886 'HalfCaste Act' more clearly resonates with the dominant political concerns that have shaped both the field of Aboriginal History and the theorisations of settler colonialism that developed alongside it, the 'Half-Caste Act' has dominated the scholarship. The latter piece of legislation drew a distinction between 'fullbloods' and 'half-castes' in ways that now seem to presage the biological, social and cultural engineering whose legacies troubled the memory politics of late

9 VPD (1869): 1726.

10 Ann Laura Stoler, Carnal Knowledge and Imperial Power: Race and the Intimate in Colonial Rule, University of California Press, Berkeley, 2002: 43.

11 Andrew Porter, Religion Versus Empire, Manchester University Press, Manchester and New York, $2004: 40$. 
twentieth-century Australia. Moreover, if ever there was a piece of legislation that exemplified the 'logic of elimination' that Wolfe so carefully discerns at the heart of the settler colonial encounter, then the Act that bureaucratically expelled 'half-castes' from the meagre entitlements of state protection offered to 'Aborigines' seems paradigmatic. ${ }^{12}$ So too, the temptation to read the 1869 Act only in relation to the 1886 Act is strong. For Henry Reynolds, these different strategies of management indicate a much wider instability in ideas about race in this period. In apparent contrast, Geoffrey Smithers and others collapse any distinction entirely and argue that both the 1869 and 1886 Acts were intended to 'facilitate the evolution of the half-caste Aborigines to white society' ${ }^{13}$ The lack of sustained anaylsis of the formation of the 1869 Act seems a little strange given the wider significance of this earlier legislation. As Katherine Ellinghaus notes, Victoria was the first Australian colony to 'legislate for a system of administration for Indigenous people living inside its borders', and others suggest the 1869 Act provided the model for protection legislation across the Australian colonies (and later, the states). ${ }^{14}$ Perhaps, then, we should resist the temptation to read this legislation through or against the strategies of biological assimilation that were hinted at by the 1886 Act (regardless of whether this comparison reveals their origin or indicates that they were yet to be historically possible).

The scholars who do pay close attention to the 1869 Act have been much more concerned to trace its relationship to the development of the reserve system in the 1860s, or compare its stated ambitions to its material effects. Richard Broome and Michael Christie both argue that the Act exemplified the form of paternalistic management that had unfolded in the 1860s. Christie argues, for example, that the Act was 'framed by paternalistic, well meaning men, intent on protecting Aborigines physically and morally and yet it limited the rights and freedom of the Aborigines to such an extent that even the dignity of deciding their own fate seemed lost' ${ }^{15}$ Whereas Patricia Grimshaw's impressive body of work has regarded the significance of the Act in relation to the material effects it had on Indigenous lives across the late nineteenth century and the ways in which

12 Patrick Wolfe, 'Nation and MiscegeNation: discursive continuinty in the post-Mabo era', Social Analysis 36, 1994: 93-152. Indeed, according to historians like Michael Christie, the practices enabled by the 1886 Act were 'near-genocidal' in their focus on 'half-castes' being absorbed into the broader settler community. Christie, Aborigines in Colonial Victoria: 155.

13 So too Andrew Gunstone draws a contiguous line between the 1869, 1886 and then earlier twentiethcentury Acts in administrative terms to discern a stubborn tradition of 'strong and discriminatory' practices from 1869 to 1957. Andrew Gunstone and S Heckenberg, 'The Government Owes a Lot of Money to Our People': A History of Indigenous Stolen Wages in Victoria, Australian Scholarly Publishing, Melbourne, 2009: 17. Felicity Jensz similarly draws a contiguous line between the Acts to suggest that racialising dynamics simply became 'increasingly strident' in the intervening years. Felicity Jensz, German Moravian Missionaries in the British Colony of Victoria, Australia, 1848-1908, Brill, Leiden, 2010: 14.

14 Katherine Ellinghaus, 'Regulating Koori marriages: the 1886 Victorian "Aborigines Protection Act"', Journal of Australian Studies 67, 2001: 23.

15 Christie, Aborigines in Colonial Victoria: 177. 
Aborigines carved out spaces within this draconian regime. ${ }^{16}$ With a similar focus upon the material effects of the Act, Attwood traces how it formed but one element in the repertoire of management that constrained life in the reserve system. ${ }^{17}$ In different, but related, ways, Marguerita Stephens argues that closer attention to the 'material ... and practical dispossession' of Indigenous Victorians reveals a substantial gap between the seemingly humanitarian character of the legislation and the blunt ideas about racial difference that structured everyday life in the colonies. ${ }^{18}$

What might happen, though, if we interrogate this piece of legislation and the discursive landscape that enabled its production not as a mechanism to reveal the gap between formation and material effect nor as a precursor to its 1886 revision? I would like to suggest that returning a sense of historical contingency to the 1869 Act, through a close analysis of shifts in thinking about 'protection' and the ethnographic 'character' of Aboriginal people, can more carefully explain how they became the objects and subjects of this form of settler colonial governance in the first place. ${ }^{19}$ As Catherine Hall argues, we need to remember that 'processes of differentiation ... were constantly in the making' rather than implying that colonised peoples were subjects acted upon by strategies of colonial rule. ${ }^{20}$ This means, at the very least, carefully tracing how ideas and practices of differentiation mediated the tension that Indigenous peoples produced as equal (British) subjects with unequal rights. ${ }^{21}$ Indeed, this Act - and the decade-long campaign by the CBPA to produce it - might be understood as a moment in which Aboriginal subjects were constituted in relation to a transforming liberal state. Patrick Joyce suggests historians should consider how the 'rule of liberal freedom' was a technique through which specific entities (in this case people) became both comprehensible objects of government and, in doing so, rendered specific elements of their lives subject to rule and regulation. ${ }^{22}$ In the colonial context (a crucial site at which these liberal techniques and strategies were first expressed) an imagined boundary between settlers and colonised subjects

\footnotetext{
16 See, for example, Patricia Grimshaw, 'Rethinking approaches to women in missions: the case of colonial Australia', History Australia 8(3), 2011: 7-24.

17 Bain Attwood, Making of the Aborigines, Allen \& Unwin, Sydney, 1989: 85. Indeed, for Attwood a key significance of the Act lay in the fact that missionaries often saw a resort to legislative authority as a threat to their religious legitimacy rather than its compliment.

18 Marguerita Stephens, 'White Without Soap: Philanthropy, Caste and Exclusion in Colonial Victoria' unpublished PhD thesis, University of Melbourne, 2010: 6 .

19 Rather than considering the gap between the material governance of Aboriginal people and the legislation that fantasised about its smooth operation, or, regarding the legislation only in as much as it contained the seeds of practices and strategies that would take their full effects much later in the century, it is worthwhile remembering that this was the first piece of legislation that transformed Aboriginal people into distinct subjects of governance in the laboratories of settler colonial statehood.

20 Catherine Hall, 'Introduction', in Cultures of Empire: Colonizers in Britain and the Empire in the Nineteenth and Twentieth Centuries: A Reader, Manchester University Press, Manchester, 2000: 20.

21 This phrase is taken from the title of Julie Evans et al., Equal Subjects, Unequal Rights: Indigenous Peoples in British Settler Colonies, 1830-1910, Manchester University Press, Manchester, 2003.

22 Patrick Joyce, The Rule of Freedom: Liberalism and the Modern City, Verso, London, 2003: 2-7, 187.
} 
provided a mechanism through which the repertoire of governable acts was both organised and differentiated. Moreover, the Act took shape in the wake of profound transformations in the relationship between the colonial state and its settler subjects - first in the devolution of self-government and then through the speedy achievement of manhood suffrage within these polities. These reformulations of colonial rule were, as Ann Curthoys and Jessie Mitchell have shown, profoundly and ambivalently racialised projects. ${ }^{23}$

In the chapter that follows, then, I draw together some of the competing ideas about practices of protection that took shape in the crucial years between the formation of the CBPA in 1860 (and the 1858 Victorian Select Committee that preceeded it) and the passing of the 1869 Protection Act. I ask how the endless political and bureaucratic murmurs about the management of the so-called Aboriginal problem legitimated a specific suite of techniques through which Aboriginal lives could be governed. Or, to put this another way, this chapter wonders how the 'Aborigine' became a governable subject of such coherence and specificity that the Act passed in 1869 without a single question raised about its exceptional powers. I do this by first tracing the emergence of 'protection' in colonial Victoria and the ways in which colonial administrators both adopted and adapted metropolitan humanitarian discourses. This adoption, I suggest, offered the solution to a series of uncertainties that took shape about the legal status of the 'Aborigine' in 1860s Victoria. This adoption and adaption, though, required some serious discursive work. Evangical ideas about protection were not simply implemented by the CBPA, they were recast in ways that offered the Board a unique way to imagine a settler colonial future that, for a brief moment, included Aboriginal people within it. In contrast to both the majority of evangelicals and settlers of a less humanitarian persuasion, in the years between 1860 and 1869 the Board suddenly argued that practices of protection might not only save the souls of Aboriginal people but secure their more earthly generational future. Returning a sense of contingency to those crucial years of debate and contestation can explain why this 1869 Act took shape in the ways that it did.

23 Ann Curthoys and Jessie Mitchell, 'The advent of self-government, 1840s-1890', in Alison Bashford and Stuart Macintyre (eds), The Cambridge History of Australia, Volume 1, Cambridge University Press, Melbourne, 2013. 


\section{The emergence of 'protection' in colonial Victoria}

When the member of the Legislative Council Thomas McCombie called for a parliamentary investigation into the condition and treatment of Aboriginal people in 1858, he argued that there was 'scarcely a spot ... where the weary aborigine could rest his weary feet [because] Victoria [was] now entirely occupied by a superior race'. Whilst few colonists could make a confident claim about the number of Aboriginal people who had managed to survive the onslaught of pastoral expansion in the 1840s and 1850s and the sudden explosion of unruly settlers during the gold rush, it was clear that Aboriginal communities had suffered severe depopulation because of that all-too-familiar settler colonial story of violence and disease. By the late 1850s, these decimated communities had been completely terrorised and traumatised by violence and death. Aboriginal communities in the 1850s, largely organised around kin relations, had lived through the death of at least half their family members in 20 years, and around 2,000 survivors were struggling to find a social and economic space in amongst a settler community that was indifferent at best and hostile at worst. ${ }^{24}$ The practice of begging that Lynette Russell traces elsewhere in this collection was one example of how Aboriginal people were adjusting to this radically transformed environment.

In this context, McCombie spoke with force and conviction about the need to do 'something towards obtaining a measure of justice towards the aborigines' in colonial Victoria. Whilst he did 'not deny the right of the higher race to take possession of the land', he was convinced that the 'right' of the colonists also entailed an obligation to perform their 'duty to the original owners' ${ }^{25}$ McCombie's committee suggested that the colonial state should grant 'protection and assistance ... to the aborigines of Victoria' through a series of land grants for missionary activity, a regular apportionment of state funds for their basic 'needs and wants' and a central administrative board to oversee their 'amelioration' ${ }^{26}$ In late May, six men with 'interest and knowledge' in the Aboriginal problem were appointed to oversee the 'protection' of this 'unfortunate race'. ${ }^{27}$

The idea that Indigenous peoples needed protection from the onslaught of settler expansion was hardly new to discussions about imperial policy. Nourished by the humanitarian turn of the early nineteenth century, evangelicals in Britain had long argued for less destructive forms of settler colonisation. So too, by

24 I owe a significant debt to Tracey Banivanua Mar for helping me to humanise these 'numbers' in this way.

25 The Victorian Hansard Containing the Debates and Proceedings of the Legislative Council and Assembly of the Colony of Victoria: Volume 4, W Fairfax, Melbourne, 1860: 110.

26 The Argus, 15 March 1860: 4.

27 The Argus, 13 May 1860: 6. 
the mid-nineteenth century, claims to respectability by middle-class men were often justified by a demonstration of acute moral sensibility, this included the compassionate treatment of those in need of protection. As Catherine Hall notes, in British public life in the 1840s, 'to be a supporter of the weak and dependent - women, children, enslaved people and animals - constituted part of the independence of middle class masculinity'; it was no coincidence that McCombie was campaigning for colonial separation and self-government as he proposed a more sympathetic demeanour towards the Aboriginal population. ${ }^{28}$ McCombie had mobilised precisely this kind of claim in his persistent assertions about the obligations of settlers since his arrival in the colonies in the mid1840s. As he had written whilst editor of the Port Phillip Gazette in 1846, 'the community ... owe it as their solemn duty to do everything in their power to promote the welfare of the aborigines' ${ }^{29}$ In this sense, the history of protection was always constitutively entangled with ideas about collective legitimacy, the political order and practices of governance (both over an independent self and its dependent others).

The flowering of humanitarian sentiment in the decades before McCombie claimed political independence through assertions of moral responsibility was a crucial element of this transformation; like the anti-slavery campaign that recast British political life at the turn of the century, the project of offering 'protection' for native peoples amplified questions about the costs and responsibilities of historical progress both in the colonies and the metropole. For some historians, the 1837 Select Committee in London represented the high-water mark for this movement; ${ }^{30}$ this committee and its recommendations sutured together a brief consensus at Westminster about the need to atone for the 'sins of the settlers' whilst also offering protection for the survivors of recent and future expansions. ${ }^{31}$ Indeed, the impact of humanitarians on imperial policy in the 1830 s - or at least, their impact on how it would be discussed in British public life - was enabled by the wider evangelical revival of the previous 30 years. Even by the 1820s, a broadly consensual form of British Protestantism had emerged that enabled missionaries to collectively craft a self-image in stark opposition to the violence of dispossession. ${ }^{32}$

28 Catherine Hall, Civilising Subjects: Metropole and Colony in the English Imagination 1830-1867, Chicago University Press, Chicago, 2002: 34.

29 Port Phillip Gazette, 11 May 1846, and 16 May 1846, np.

30 Alan Lester, 'Humanitarians and white settlers in the nineteenth century', in Norman Etherington (ed.), Missions and Empire, Oxford University Press, Oxford, 2005: 64.

31 Elizabeth Elbourne, 'The sin of the settler: the 1835-36 Select Committee on Aborigines and debates over virtue and conquest in the early nineteenth-century British white settler empire', Journal of Colonialism and Colonial History 4(3), 2003, online.

32 Hilary Carey, God's Empire: Religion and Colonialism in the British World, Cambridge University Press, Cambridge, 2013: 10; see also, Anna Johnson, Missionary Writing and Empire, 1800-1860, Cambridge University Press, Cambridge, 2003: 14. 
The development of the Aboriginal Protectorate in Port Phillip flowed directly from these concerns and the committee in particular. In the year before his resignation from the stewardship of the Colonial Office, Glenelg - a figure already embroiled in contestation with settlers at the Cape over their treatment of Indigenous peoples - authorised the deployment of four 'protectors' to the new colony of Port Phillip. Having been first settled by entrepreneurial fiat a few years before, this accident of historical proximity meant that the Colonial Office was trying to manage the expansionist efforts of settlers in Port Phillip in the wake of the select committee. The 'protectorate' as Jessie Mitchell notes, was an early attempt to negotiate between the philanthropic efforts of missionaries and the ever-changing structures of colonial administration. Although this was always an ambivalent negotiation as missionaries usually contrasted their own form of religious interventions with the apparent moral paucity of colonial administrators. $^{33}$

By the time the CBPA first convened in 1860, however, the earlier Protectorate was widely regarded as a complete failure (and frequently discussed in these terms in colonial public life). ${ }^{34}$ In 1849, all but one of the Protectors had been dismissed (although figures like Edward Parker remained in the colony and attempted to forge ahead with humanitarian projects). Nonetheless, in the intervening years, missionary endeavours had begun to haltingly take root in the colony. Presbyterians formed missionary committees and Anglicans did the same, eventually producing enough support to sustain the employment of a missionary on land allocated by the colonial government at Mount Franklin. Moravian missionaries arrived in the early 1850 s and stumblingly tried to encourage Aboriginal people onto their doomed Lake Boga mission. By the time the 1858 Select Committee made its recommendations, the ad-hoc system of government grants for missionary endeavour was beginning to take shape and the CBPA was designed to formalise, oversee and more carefully administer the disbursement of this obligation.

Ironically, then, even though historians like Lester suggest that the 1837 Select Committee seemed like the peak of humanitarian influence over colonial policy - and in the metropole it certainly was - in the newly self-governing Colony of Victoria in the late 1850s, the idea and practice of protection once again gathered steam. Over the 1860s, the CBPA would develop a network of guardians to oversee the distribution of clothing and rations across the colony, shape and support missionary practice (although this relationship was sometimes unclear), and secure a system of reserves within which, they thought, Aboriginal people

\footnotetext{
33 Johnson, Missionary Writing and Empire, 1800-1860: 33.

34 Although, as Jessie Mitchell notes, these claims about failure were as much about justifying certain practices of management in their own present rather than a reflection on the inadequacy of the Protectors. Jessie Mitchell, In Good Faith? Governing Indigenous Australia Through God, Charity and Empire, 1825-1855, Aboriginal History Inc. and ANU E Press, Canberra, 2011: 31.
} 
could find respite from land-hungry settlers. By the end of the 1860s, the Board oversaw a network of six stations, including its own reserve modelled upon, but without the evangelical justification for, missions. However, questions about the relationship between Aboriginal subjects and the transforming colonial state constantly challenged the CBPA's activities in the 1860s. The Board was - in its original form - established as a mechanism to distribute near-evangelical care and compassion rather than necessarily 'govern' Aboriginal people. At the same time, however, the activities of the Board itself mobilised the strategies and techniques of governance that so many scholars have suggested were at the heart of an emerging liberal modernity in Britain and its colonies. The Board collected information about the health of Aboriginal people, monitored their presence and treatment in the judicial system and employed this knowledge in an attempt to control their behaviour. Whilst constantly hampered by their ambivalent position within the bureacracy of the state, and their capacity to exert authority over their apparent charges, the Board did much more than simply distribute evangelical protection.

\section{Protection as a strategy of governance}

Recent work has begun to carefully consider the ways in which the progressive story of liberal modernity might be retold as a much more tenuous and inchoate process in which the relationship between the state and its subjects was constantly reconfigured and reassembled through boundary contests over the public and the private, the market and the family, and the individual and the collective. Rather than considering liberalism as a mechanism through which citizens could claim rights, we can, instead, ponder how liberalism functioned as a technique of government in which 'markets, civil society and everyday life' became sites at which the limits of state intervention would be negotiated. ${ }^{35}$ The citizen of liberal modernity was only made possible through a shifting set of boundaries that established certain practices as private and others as subject to state intervention. Seen in this light, the history of the Board could be a story of how these boundaries were imagined through their suspension. In the 1860s, moreover, the colonial state was in the process of 'being put together', as probably the best known historian of the Australian state Alastair Davidson points out. Significantly, though, Davidson virtually ignores the history of the 1869 Protection Act, collapsing the 'failure' of the Port Phillip Protectorate into a story of systematic neglect over much of the second half of the nineteenth century, misdating the opening of Framlingham by 50 years and ignoring

35 James Gunn and Simon Vernon, 'Introduction', in James Gunn and Simon Vernon (eds), The Peculiarities of Liberal Modernity in Britain, University of California Press, Berkeley, 2011: 9. 
the intersection between missionary practice and the CBPA completely. ${ }^{36}$ If 'markets, civil society and everyday life' formed a crucial site at which the relationship between the state and its subjects would be imagined, then it is hardly a surprise that these three registers - and the place of Aboriginal people as subjects before the law - were central concerns for the Board in its first decade. Liberal governance is, moreover, not only a practice of managing the relationship between the state and its subjects; it is a technique through which subjects will manage their relations with each other. For the Board, the relation between settlers and Aboriginal people - and how they might be regulated - loomed large as their most pressing problem. Early in the decade the Board attempted to deploy various mechanisms of the state to manage the treatment of Aboriginal people in the colony, soon, however, it became apparent that attempting to moderate how settlers treated Aboriginal people specifically within the existing organisation of legal authority was almost impossible.

For example, the sale of 'intoxicating liquor' to Aboriginal people had been a concern of the CBPA since its first meeting and humanitarians in the colony had long suggested that the drunkenness was one of the more disturbing 'vices' that accompanied colonial expansion. Soon the Board would suggest the 'the necessity of taking strenuous measures to abate the sale of intoxicating liquors to the blacks' ${ }^{37}$ The sale of liquor to Aboriginal people was, in fact, already prohibited by the legislation the colony had inherited from New South Wales. This restriction had been instantiated to 'protect' settlers from the apparent violence of intoxicated Aboriginal people as much as 'protect' Aboriginal people from the 'vice' of drunkenness. ${ }^{38}$ The Board in Victoria was not exempt from this kind of thinking, earlier suggesting that 'several murders have been committed by the blacks who have procured intoxicating liquors' ${ }^{39}$ In New South Wales, a shift away from the 'conception of Aborigines as enemy' meant this restriction would be removed in 1862. In Victoria at the same time, however, the Board engaged in a campaign to strengthen these restrictions - not to protect settlers but now to protect Aboriginal people. ${ }^{40}$ From its earliest meetings, it sent letters around to police magistrates in the colony to remind them that the legislation inherited from New South Wales restricted the sale of alcohol to Aboriginal people to try and compel the enforcement of this restriction. ${ }^{41}$ The threat of financial punishment or the retraction of a licence to sell liquor was not, the CBPA argued, enough to compel publicans to halt these transactions. Settlers

\footnotetext{
36 Alistair Davidson, The Invisible State: The Formation of the Australian State, Cambridge University Press, Cambridge, 1991: 78 .

37 First CBPA Annual Report (1861): 6.

38 Second CBPA Annual Report (1862): 6.

39 Third CBPA Annual Report (1864): 7.

40 Anna Doukakis, The Aboriginal People, Parliament and Protection in New South Wales, Federation Press, Sydney 2006: 6 .

41 First CBPA Annual Report (1861): 8.
} 
who sold 'spirits to the blacks should not be fined, but imprisoned', so grave was the offence. ${ }^{42}$ When the colonial parliament reformed its licensing laws in 1864, the Board worked hard to ensure that the restrictions inherited from (but since withdrawn within) New South Wales stayed in place in the Victorian 'Wine, Beer and Spirit Sale Statute'. Whilst the wish for imprisonment was unmet, they nonetheless achieved an increase of the penalty of sale to $£ 10$.

The Board attempted to shape economic relations between Aboriginal people and settlers in other ways as well. In matters of employment, the CBPA attempted to control how settlers would employ Aboriginal people and the conditions of contract under which that employment would unfold. Citing examples of settlers refusing to pay Aboriginal labourers and exploiting the Board's generosity in order to buck their responsibilities for sustenance, the Board noted that they had experienced 'difficulty in dealing with cases [where settlers] have taken Aborigines into employment [because] the responsibility resting on the settler and his duties towards his servant are, in some instance, unrecognised or misunderstood' ${ }^{43}$ In one case, the Board had tried to force a settler to 'give up' his servant - for reasons of apparent mistreatment - but floundered against their lack of authority. ${ }^{44}$

Similar issues unfolded when settlers proposed to contract a successful team of Aboriginal cricketers to tour England in 1866. On the back of successful Aboriginal cricket teams in the Wimmera in the early 1860s, William Hayman and Tom Hamilton hatched a scheme to train the team locally and send them to England for a tour. The Board strongly objected, suggesting that these Aboriginal men were being exploited for settler gain and the efforts of the Board to civilise the population would be undone during such a prolonged absence. They were, however, unable to draw on any legislative power to prohibit the cricketers contracting to Hayman and Hamilton for the tour; in 1867 the Aboriginal team signed on the dotted line. Indeed, David Sampson's careful work reveals that settler signatories had contradictory understandings about the legal capacity of Aboriginal people to freely 'contract with' others; some considered them legally free subjects whereas others thought they were dependants and thus their capacity for legal consent was compromised. ${ }^{45}$ The Board argued strongly that even if the latter was not the case legally, it certainly was in moral and civilisational terms. MacBain argued that if

\footnotetext{
42 Second CBPA Annual Report (1862): 10.

43 Fourth CBPA Annual Report (1864): 11.

44 Central Board for the Protection of Aborigines (CBPA), 'Minutes of meetings', March 1862, National Australian Archives (NAA), Series B314, Item 1.

45 David Samspon, "“The nature and effects thereof were by each of them understood": Aborigines, agency, law and power in the 1867 Gurnett contract', Labour History 74, 1998: 59.
} 
the trip was undertaken for the purpose of improving the status and ameliorating the degraded state of those aborigines, and for raising them in the scale of the human family, then, indeed, I would gladly assist in carrying out an object so worthy and humane; but there is too much reason to fear that such desirable results will be altogether ignored in the proposed expedition. ${ }^{46}$

The Board discovered that attempting to force settlers to acknowledge this difference was impossible; legislative restriction was the only solution. ${ }^{47}$ The 1869 Act, produced in the context of a debate between entrepreneurial settlers and the Board, granted it the right to 'prescribe the terms on which contracts for and on behalf of Aboriginals may be made with Europeans' ${ }^{48}$ The Board soon found that the notion of 'prescription' proved vague in judicial terms and the Act could not be applied retrospectively. Burnt by their experience with the cricket tour, the Board ensured that an 1871 legislative amendment meant that 'no contract with any Aboriginal for any service of employment for longer than three months shall have validity ... unless such contract shall have been approved by the Board'. ${ }^{49}$

Similar ambiguities about the status of Aboriginal people as legal subjects had long unfolded in the practice of criminal law. As Lisa Ford discovered, questions about the jurisdiction of British law over Aboriginal people in the colonies seemed to have been resolved in a series of decisions about violence within Aboriginal communities in the 1830s. ${ }^{50}$ However, as Mark Finnane notes, this did not resolve the questions about the legal status of Aboriginal people in the criminal system so much as establish they were subjects within it. Finnane's careful study of cases across the nineteenth century reveals that colonial jurisdictions frequently mobilised notions of custom, tradition, culture and race to specify and adjudicate criminal proceedings. ${ }^{51}$ Whilst earlier governors in Victoria had suggested that making the Aboriginal population 'amenable as subjects to British law' would make them more 'civilised', 52 the Board argued strongly that the operation of criminal law needed to acknowledge the specificity of Aboriginal subjects as an ethnographic group.

\footnotetext{
46 The Argus, 14 October 1867: 6.

47 CBPA, 'Minutes of meetings', NAA, Series B314, April 1865.

48 An Act to provide for the Protection and Management of the Aboriginal Natives of Victoria, 11 November 1869, Victorian Parliament.

49 Sampson, 'The nature and effects': 64

50 Lisa Ford, Settler Sovereignty: Sovereignty: Jurisdiction and Indigenous People in America and Australia, 1788-1836, Harvard University Press, Harvard, 2011: passim.

51 Mark Finnane, 'Settler justice and Aboriginal homicide in late colonial Australia', Australian Historical Studies 42(2), 2011: 244-259.

52 Quoted in Frances Thiele, 'Superintendent LaTrobe and the amenability of Aboriginal people to British law', Provenance 8, 2009: 3.
} 
From 1860, the Board attempted to mediate between the colonial criminal system and Aboriginal people in Victoria. These subjects, the Board argued, represented an exception to the notion of equality before the law - nowhere was this more evident than in how sentences were handed down. From 1860 'criminal law as it effects the blacks was considered by the Board' and they soon argued that the judiciary needed to 'take steps' to 'mitigat[e] ... the severity of our laws, as they effect Aboriginal criminals'. Because of the

character of the black ... the effect of close imprisonment on one of this people is to deprive him of all hope and gradually reduce him to a state of imbecility. Accustomed to freedom in its widest sense, the restraint of a gaol produced a lethargy which in cases of prolonged improvement results in death. ${ }^{53}$

The Board wrote letters to the Attorney-General to try and seek the reduction of specific sentences, mobilised its resources to try and produce more careful representation by counsel in criminal proceedings, and even sought pardons from the Governor in cases already heard. ${ }^{54}$ From 1863, the annual reports began to tabulate the number of Aboriginal people currently incarcerated for criminal offences in the colonies, arguing 'that close imprisonment is not the kind of punishment to which an Aboriginal should be subjected' ${ }^{55}$ The great irony was, of course, that the Board was attempting to gain only a slightly different kind of disciplinary control over Aboriginal lives. Throughout the 1860s, though, the Board was constantly frustrated by the rigidity of the criminal justice system - just as it could not force settlers to adjust their engagements with Aboriginal people, so too, attempting to mediate between the judiciary and Aboriginal people was difficult. Even whilst they mobilised the powerful vocabularies of difference that were beginning to have substantive purchase in colonial life, they were constantly stymied by the difficulties of forcing a judicial system to acknowledge ethnographic difference with consistency. Unless Aboriginal subjects were recognised as having distinct legal status, they would be unable to govern them effectively.

Indeed, within six months of the Board's first meeting in 1860, its members had noted that their precise relationship (both to the colonial state and to Aboriginal people) was ambiguous at best. As soon as the Board was appointed, its secretary sought clarification about its position within an expanding colonial government and the 'Commissoner of Lands and Survey' had confirmed that 'the government would offer every facility to the Board to carry out its views'. The scope and limit of the Board's capacity to shape the purpose of its work,

53 First CBPA Annual Report (1861): 7.

54 CBPA, 'Minutes of meetings', NAA, Series B314, May 1861. 
organise the allocation of its resources and intervene into the lives of its charges was still unclear. In June, it was 'ultimately agreed' that the Board would 'stand adjourned ... until the powers to be entrusted them should be clearly defined in a commission issued for that purpose, as to the control of officers and the disbursement of funds ... which at present they cannot claim' ${ }^{56}$ The Board's place within the colonial bureaucracy was soon clarified, it would be 'subject to the political responsibility of the Department of Land and Survey' but would have the freedom to decide how its financial recourses should be distributed and the mechanisms by which this care and protection should be offered.$^{57}$ The question of how much control the Board would have over Aboriginal people was, however, left unanswered. Later that year, the Board had pleaded for legislative clarification about who would have 'custody of Aboriginal minors', suggesting that power might be granted to the governor, whose authority the Board could then mobilise to take control of Aboriginal children, but these negotiations stalled as their chairman Heales was soon entangled with the machinations of the rise and fall of government ministries and his brief episode as chief secretary. ${ }^{58}$

In 1862, the Board, in consultation with the Attorney-General, drafted a Bill to grant them more powers to control the movements and residence of Aboriginal people as well as custodianship of all Aboriginal children. In May, Brough Smyth reported on a meeting with the current minister of Justice 'who held out no hope of such a Bill being brought in this session' ${ }^{59}$ The Board took matters into its own hands, and submitted the Bill by deputation to the chief secretary in September of that year; it was continuously postponed due to the 'other pressing demands on the attention of the legislature' ${ }^{60}$ Heales attempted to form another select committee in the legislature in 1863 to provoke a discussion of the problem of governing Aboriginal people, but the attempt floundered after initial support in the Legislative Assembly, defeated by the apparent indifference of colonial legislators. Soon the Board registered their frustration in their annual report, noting in 1864 that 'their urgent solicitations for some amendment of the laws affecting the blacks have not yet received attention' ${ }^{61}$ Two years later their frustration was growing, and they noted that

nearly three years have elapsed since they furnished the draft of a Bill; and they regret to say that the circumstances of the colony have

56 CBPA, 'Minutes of meetings', NAA, Series B314, June 1860.

57 CBPA, 'Minutes of meetings', NAA, Series B314, August 1860.

58 CBPA, 'Minutes of meetings', NAA, Series B314, September 1860.

59 CBPA, 'Minutes of meetings', NAA, Series B314, May 1862.

60 CBPA, 'Minutes of meetings', NAA, Series B314, November 1861, see also, September 1862

61 Third CBPA Annual Report (1864): 4. 
prevented your Excellency's advisors from taking those steps which are so urgently needed for the protection of the Aborigines ... under the present circumstances [the Board] can do little. ${ }^{62}$

Finally, in the next year, the Board would achieve the legislative authority it had so desperately sought. The Act passed in 1869 granted them control over where Aboriginal people lived, how their children were raised, how their employment with settlers would be managed and what happened to their earnings. The Board had effectively inserted itself between Aboriginal people and their relations with employers, their children and the state whilst, at the same time, claiming power to force them onto the system of reserves and missions. 'Protected by a just law,' the Board claimed, 'there is hope this people may yet be preserved.'63

Over the previous 10 years, the Board had developed a set of strategies that resonated with the key concerns of the emerging liberal state. Moreover, given the CBPA had 'scrambled' for authority in its early years and constantly complained about the ambiguous legal status of Aboriginal subjects, this was quite a transformation. Part of the explanation for this new-found legitimacy was, of course, the mobilisation of long-standing ideas about protection that were nourished by evangelical thought. Clearly, this legislatively empowered protection was, however, no straightforward adoption of evangelical practice. Crucially, some of the dominant elements of evangelical thought about Aboriginal people were recast and challenged by the Board in the mid-1860s - not least in a different imagining of the temporal future of Aboriginal people. Whilst the 1869 Act might be read as the combination of liberal strategies of rule and evangelical ideals of protection, their discursive entanglement only became possible after the CBPA recast some of the assumptions of their evangical allies.

\section{Glimmers of an Aboriginal future}

Questions about the future of Indigenous peoples had reverberated in discussions of the settler empire long before the instantiation of the Board in 1859. Settler colonialism was (and is) a project of (violent) historical transformation - it inevitably raised questions about the near and distant future of the peoples both propelling and struggling against its territorial imperatives. Whilst the hardening of racial categories as the century unfolded provided fertile, imaginative ground for the perception of Indigenous extinction (and thus a powerful vocabulary for settlers to enact it), earlier ideas about religiously ordained imperial progress and human difference could sustain similarly morbid predictions of the coming disappearance of native peoples across the settler empire. As Patrick Brantlinger

62 Fifth CBPA Annual Report (1866): 18.

63 Sixth CBPA Annual Report (1869): 8. 
demonstrates, whilst the biological (and blood) based arithmetic of 'race' did not take shape until the later nineteenth century, what would become ideas about the 'doomed race' in the 1880s had their antecedents in earlier predictions about the demise of native peoples in the face of imperial expansion. ${ }^{64}$

Nontheless, there were important differences between these narratives of decline and disappearance. The later perception of the 'doomed race' was, as Henry Reynolds and Marilyn Lake note, deeply entangled with transnational ideas about the historical destiny of 'white man's countries' and the rigid categories of racial difference that underwrote them. ${ }^{65}$ In the mid-nineteenth century, however, the ghosts of anti-slavery campaigns haunted British vocabularies of human difference and capacity; the various 'experts' who governed the empire were torn between assertions of human brotherhood and stubborn evocations of ethnographic difference. Importantly, though, Brantlinger points out that even evangelicals nourished by humanitarian turn in the 1830s were ambivalent about the possibilities of earthly Indigenous futures. Mid-nineteenth-century predictions of immanent disappearance - which were common to observers in both the periphery and the metropole - were powerfully shaped by a story of melancholic lament. Evangelical vocabularies provided powerful discursive mechanisms through which the colonising subject could both enact and lament the destruction of Indigenous peoples as both a loss and incorporation into the colonising self. To add even more complexity to this picture, the categories through which these mid-century discussions unfolded were sometimes understood as historically immutable and sometimes transitory - unstable ideas about the latter meant that even those who contested the notion of inevitable decline were uncertain about whether individual Aboriginal people could be 'civilised' or if the 'civilisation of the Aborigine' would unfold in generations to come.

As Lynette Russell suggests, moreover, narratives about the apparent 'demise' of Aboriginal Tasmanians reverberated through Victorian public life in the 1850s to provide yet more evidence for this kind of thinking. ${ }^{66}$ The Geelong Advertiser declared in 1855 that the 'Aborigines of Tasmania [are] a race now nearly extinct ... the inferior race has slowly but steadily yielded; and though long succoured and protected, there is now a mere handful of the aboriginal inhabitants left' ${ }^{67}$ So too, in a tidy disbursement of responsibility, the apparent failure of the Port Phillip Protectorate in the 1840s could be easily marshalled to suggest that settlers were powerless to effect any change. The Victorian 1858 Select Committee was

64 Patrick Bratlinger, Dark Vanishings: Discourse on the Extinction of Primitive Races, 1800-1930, Cornell University Press, New York, 2003: 17-44.

65 Marilyn Lake and Henry Reynolds, Drawing the Global Colour Line: White Men's Countries and the International Challenge of Racial Equality, Cambridge University Press, Cambridge, 2008: 137-165.

66 Lynette Russell, forthcoming.

67 Geelong Advertiser, 25 September 1855: 3. 
keen to discover the cause of the 'great and almost unprecedented reduction in the number of the Aborigines' and McCombie's report suggested that, like other experiences of colonisation, the 'general occupation of the country by a white population ... the scarcity of game ... in some cases, cruelty and illtreatment ... [and] the vices acquired by contact with a civilized race' had proved disastrous for Indigenous peoples in the colony ${ }^{68}$ It was a short step to remove any responsibility for this destruction from settlers themselves; they simply became signifiers of historical change rather than its agents.

Witnesses to the 1858 Select Committee were asked if 'they could be saved from ultimate extinction' and even humanitarians like William Thomas, who argued for a system of care and protection, suggested that 'extinction must be the sequel of this hapless race'. ${ }^{69}$ Many other settlers, often whilst supporting the development of reserves, similarly predicted an eventual disappearance; landholding settlers and amateur ethnographers like William Beveridge suggested their 'final extinction' was inevitable. Frederick Godfrey similarly argued that because 'blacks were confirmed in, and by natural capacity adapted for, their wild roving life of freedom', they could not carve out an existence in the changed circumstances of colonisation. Godfrey worked hard to 'ameliorate' the conditions of Indigenous people around the Loddon district and was known as 'the Loddon blacks' best friend'. He nonetheless thought that even though many of the 'young could be reclaimed and civilized ... their final extinction seems the inevitable law of nature'.$^{70}$ Similarly pessimistic predictions were made in both parliament and the colonial press, soon, 'they would cease to exist, except in name' suggested The Argus, and any effort by the settlers to improve their condition was a moral and religious project in the present rather than an endeavour with an historicised future. ${ }^{71}$ One settler gloomily predicted that 'attempts to reclaim the aborigines to the ranks of civilization' were doomed to fail. ${ }^{72}$

Even as these laments papered over a history of mistreatment and violence (or at least made this violence the exception rather than the logic of settler colonial rule), they did not necessarily justify indifference in their own present. Indeed, the notions of compassion and sympathy that often framed these predictions also worked as a mechanism to secure humanitarian intervention; evangelicals in the colony repeatedly imagined themselves in opposition to this apparent indifference suggesting that, instead, settlers owed a moral debt to the 'remaining

68 Report of the Select Committee of the Legislative Council on the Aborigines; together with the Proceedings of the Committee, Minutes of Evidence, and Appendices, Government Printer, Melbourne, 1859: v.

69 Report of the Select Committee of the Legislative Council on the Aborigines (1859): 27.

70 Report of the Select Committee of the Legislative Council on the Aborigines (1859): 21.

71 The Argus, 19 July 1861: 5.

72 The Argus, 7 September 1866: 7. 
blacks' ${ }^{73}$ When McCombie tabled his report to the colonial parliament, he spoke powerfully about 'obtaining a measure of justice for the blacks' and ensuring their protection from the 'moral outrages [of] some colonists' ${ }^{74}$ So too, missionaries made potent claims that settlers owed Aborigines their 'protection'. As Anne O'Brien notes, humanitarians wove together ideas about justice and British rule to argue that colonists should deliver Aboriginal people a form of reparations for their dispossession. ${ }^{75}$ When he opened a meeting of the Board of Australasian Missions, the Anglican Bishop of Sydney suggested that 'in the occupation of their soil we are partakers of their worldly things ... natural and much more Christian equity points out [that] in justice they should be of our spiritual [concern]'. ${ }^{76}$ Again and again, throughout the Australian colonies in the mid-nineteenth century, missionaries and humanitarians would argue for government support for missionary intervention; the revelation of the gospel and care for the physical 'wants' of Aboriginal people would represent a 'measure of justice' for dispossession. ${ }^{77}$ As the chair of the Anglican 'Mission to the Aborigines' meeting noted in 1857, it was an 'act of pure justice that an effort should be made to convey to them the privileges of the Christian religion' ${ }^{78}$

However, the actions of evangelicals were framed by a markedly different temporality than the (near and distant) earthly future that shaped the emerging institutions of colonial governance. As the chair of the 1860 meeting of the Church of England Mission to the Aborigines noted, 'God estimated the value of a single soul more highly than any more temporal matters' ${ }^{79}$ Spiritual reclamation was the crucial lens through which any material action unfolded. As the missionary Frederick Spieseke noted when he spoke to a capacity audience at the Melbourne Mechanics Institute regarding Moravian missionary efforts in Victoria, their endeavours were shaped not only by an attempt to ameliorate their 'fearful [material] state' but also to ensure their 'Christianization'. Moravian efforts were not only concerned with 'their bodies but [also] with their souls', which should be 'reclaimed' before their extinction. Indeed,

\footnotetext{
73 Report of the Select Committee of the Legislative Council on the Aborigines (1859): iii.

74 VPD (1859): 789.

75 Ann O'Brien, 'Humanitarianism and reparation in colonial Australia', Journal of Colonialism and Colonial History 12(2), 2011, http://dx.doi.org/10.1353/cch.2011.0016

76 The Herald, 2 November 1850: 2.

77 This phrase appears frequently, The Perth Gazette and Independent Journal of Politics and News, 14 November 1851: 4; The Argus, 27 October 1858: 4. What had taken shape as a claim for justice in the context of frontier killings had, in NSW, Vic and SA by the mid-century become a powerful mechanism to justify humanitarian intervention. Even the Catholic Bishop of Melbourne offered a scathing account of the culpability of settlers. The Bishop noted that it was 'a melancholy fact that the reason why the numbers of savage tribes had always diminished in every country in which civilized man had set his foot was in consequence of the wickedness of many of those people who professed and called themselves Christians. The mere fact of civilized men living in countries inhabited by savages was not the cause of the savages declining in numbers.' Receiving 'the gospel and manifesting the truth in their lives' could ensure their survival.

78 The Argus, 20 August 1857: 5.

79 The Argus, 20 January 1860: 5.
} 
whilst the annual reports for the CBPA in the 1860s made careful calculations about mortality and living conditions, the Moravian missionaries in the $1850 \mathrm{~s}$ calculated their success in spiritual terms; successful conversions functioned as the central economy of evangelicism. ${ }^{80}$ So too, the Anglican missionary Thomas Goodwin encouraged his fellow Victorians with an account of the successful conversion he recently witnessed in South Australia. Whilst the 'blacks ... by many persons are deemed ... unsusceptible of religion', in South Australia he discovered 'a remnant, it is true, but yet a people ... worshipping Him whom their fathers knew not, but who, by His all-powerful grace, they have been brought to know and love'.$^{81}$ Moreover, like the long history of evangelical practice that preceded them, at the various public meetings held to secure support for missionary activity in the colony, stories of individual conversion provided crucial nourishment for the arduous project of mission work. Whilst the earthly treatment of Indigenous people in the present could be understood to exert a powerful claim on colonists, evangelical thought was not necessarily shaped by a concern to ensure the generational future of these communities.

Seen in these terms, it is no surprise that, unlike the broader public culture of the colonies, missionaries and their supporters did not adopt a uniform position about the earthly fate of Aboriginal people. Michael Christie argues that in the 1850s and 1860s, humanitarians adopted the twin projects of 'Civilization and Christianization' as the centerpiece of Aboriginal policy. ${ }^{82}$ The entanglement of these ideas in the 1860s was not based, however, on an assumption that missionary intervention would produce Aboriginal futures. At the first meeting of the Anglican 'Mission to the Aborigines' in Victoria, the chair noted that 'in all probability, the opportunity of attending to [evangelical activity] will, with the natives themselves, be passed away for ever'. Even as he wanted to 'guard the Members of the Society against the idea that the mental standard of the Aborigines is so low that they are incapable of instruction', the Anglican Missionary Committee was far from certain this could produce a generational

\footnotetext{
80 See, for example, the discussion of Nathaniel Pepper's conversion: 'The object for which the Moravian mission was established, namely - the glory of God in the salvation of men, - has been attained in regard to at least this poor Native, and it is only due tribute of praise to God to acknowledge that every day's patient labour, every self-sacrifice of love, every dutiful act of every kind done for this Mission has been more than overpaid. God is greatly to be praised for the salvation of even one poor sinner, and each several victory over Satan and his hosts serves to inspire fresh zeal and love in the armies of the living God.' First Annual Report: Further Facts Relating to the Moravian Mission in Australia, Read in Connection with the Report of the Committee at the Annual Meeting of the Melbourne Association in Aid of the Moravian Mission to the Aborigines of Australia, Fergusson \& Moore, Melbourne, 1862: 4.

81 The Argus, 23 January 1860: 5.

82 Michael Christie, Aborgines in Colonial Victoria.
} 
future. ${ }^{83}$ Four years later, the committee would suggest that the people are passing away - soon they will be all gone, and it is our duty to work while it is called to-day' ${ }^{84}$

The possibility of extinction could even add urgency to the missionary project. At a meeting of the Anglican Missionary Committee in Melbourne in 1855, the Archdeacon of Geelong assumed that the 'Aboriginal races [would] sink into non-existence before the appearance of civilization'. This did not, however, 'exonerate' the colonists from their duty. Indeed, inaction - even if it failed to ensure their survival - would make the entire colony 'virtually murderers'. The 'words of the gospel', for the Archdeacon, could 'reach [the Aborigine's] intellect and touch his heart' if only missionaries might learn the native language. At present 'the darkened minds of the aborigines were one of the strongholds of Satan, [and] God could with perfect ease overturn these strong holds, and influence their hearts to receive the Gospel' ${ }^{85}$ Conversion and reclamation, then, were the missionaries truest calling, in spite - or perhaps even because - of their imagined disappearance. As a fellow Anglican argued, 'the night cometh on so rapidly [for Aboriginal people] that the remaining hours of the day ought to be improved to the utmost' ${ }^{86}$

Missionaries and their supporters from other denominations were, however, less certain of this earthly demise. Even in the 1850s, Presbyterian leaders and the Moravian missionaries they supported argued that spiritual intervention could be the mechanism through which the 'decline' might be prevented. Perhaps because the theological history of both these denominations encouraged a more earthly orientation, or perhaps because ideas of progressive reform were deeply entangled with Presbyterian narratives of individual and collective improvement, the network that emerged between Moravian missionaries, their supporters and Presbyterian leaders sometimes suggested that the reforming projects of 'Christianization and Civilization' could 'save from extinction the races of fallen humanity' ${ }^{87}$ In Bendigo in 1865, the Presbyterian minister (and later vice president of Scotch College) Reverend Moir delivered a lecture on the 'customs and religious beliefs of the Aborigines of Victoria'. After the lecture, he engaged in a wide-ranging discussion of the missionary efforts in Victoria with the chair and local medical practitioner. Combining their spiritual and material expertise, Dr Boyd and Rev. Moir agreed that whilst the Aboriginal

\footnotetext{
83 First Annual Report of the Melbourne Church of England Mission to the Aborigines of Victoria, Mason and Firth, Melbourne, 1854: 4.

84 Fourth Annual Report of the Melbourne Church of England Mission to the Aborigines of Victoria, Mason and Firth, Melbourne, 1858: 10.

85 Second Annual Report of the Melbourne Church of England Mission to the Aborigines of Victoria, Mason and Firth, Melbourne, 1855: 9.

86 Fifth Annual Report of the Melbourne Church of England Mission to the Aborigines of Victoria, Mason \& Firth, Melbourne, 1859: 7.

87 The Argus, 2 July 1851: 4.
} 
population had decreased most rapidly 'from want of food, scant clothing and introduction of disease', missionary activity could 'teach them the civilization of the whites' so they might find a place in the colonial future. ${ }^{88}$ Elsewhere, Presbyterians suggested that because their fellow churchman John Green acted as an 'evangelist among' Aboriginal people at Coranderrk, the 'civilization of Aborigines' could be possible when 'Christian habits (were) formed' (even though he was a secular appointment on the CBPA-run reserve). ${ }^{89}$ By the late 1860s, Ramahyuck station in Gippsland, managed and supported by the 'Moravian Mission in connection with the Presbyterian Church of Victoria', was being discussed in similar terms. The Illustrated Australian News provided a sketch of the station and directed the reader to observe the schoolhouse and other buildings to suggest that spiritual 'salvation' could produce a generational future; 'the fences, gardens and other improvements [and] the general bearing of the natives in front to the place' suggested their 'fate' was not sealed..$^{90}$

However, this Presbyterian and Moravian optimism was not widely shared. When the CBPA met for the first time in 1860, it faced a public culture in which predictions about the earthly future of Aboriginal people in Victoria was ambivalent at best and pessimistic at worst. Whilst some (but not all) evangelicals wove together the notion of 'Christianization and Civilization' to suggest that missionary action could save the spiritual and material futures of Aboriginal communities, most others found themselves in the intellectual company of wider public culture in colonial Victoria. A steady (or sometimes more sudden) generational decline was the only Aboriginal future they could imagine. In these terms, 'protection' implied moral and compassionate amelioration and a respite from settlers hungry for territory. In the first few years, the Board's practice largely reflected these ideas.

In those years, the CBPA's most pressing concern was to attend 'to the physical wants of the blacks' ${ }^{91}$ The instantiation of the Board, and the funds for rations and clothing that the parliament had offered for their task, could 'improve the welfare [of] the blacks generally' and 'preserve them from starvation'. Rather than the 'niggardly hand' the colonial state had previously proffered Aboriginal people, the Board suggested it would be an agent of 'warm sympathy' for these 'destitute' figures. ${ }^{92}$ Moreover, given the political contention that surrounded the issue of state aid, it is little wonder the CBPA was keen to avoid anything that might resemble support for specific denominational missionary intervention. Requests for aid from the Moravians in addition to the standard allocations of rations and clothing for individual Aboriginal people were firmly rejected;

88 Bendigo Advertiser, 25 October 1865: 3.

89 Australian News for Home Readers, 25 October 1865: 11.

90 Illustrated Australian News, 1 January 1869: 5.

91 Sixth CBPA Annual Report (1869): vi.

92 First CBPA Annual Report (1861): 1, 6, 12. 
funding the mission would be left to the missionaries and their network of denominationally specific supporters. The monthly meetings of the Board in the early 1860s were frequently dominated by the construction of careful distinctions between material support for Aboriginal people and financial support for missionary activity. Whilst the Board noted that 'every endeavour should be made to foster and encourage the self-denying efforts of the enlightened missionary', repeated requests for CBPA funds for the construction of mission buildings and the payment of missionaries provoked careful and lengthy discussions but were always rejected..$^{93}$ The CBPA was the mechanism through which the material obligations of the colonial state to Aboriginal people would be disbursed and missionaries could be the agents of this activity; whilst the members of the Board agreed that Christianisation was morally worthy, for the CBPA it was the mechanism through which a material obligation would be paid rather than its central object.

\section{Adjusting the evangelical vocabulary}

However, the Board faced an even bigger problem; for the state to manage the compassionate 'ameliorat[ion of] the conditions of the blacks', they needed to know where and how Aboriginal people were living. In the years after the Port Phillip Protectorate was disbanded, William Thomas - the lone guardian of Aborigines in the unruly context of gold-rush Victoria - had struggled to maintain an accurate picture of the number of Aboriginal people who were carving out a social and economic niche in the colony, let alone produce an empirically grounded account of their condition. Much like the 1858 Select Committee then, it is little wonder that the first years of the CBPA operated much like an audit. The committee's report had provided an estimate of the number of living Aboriginal people (and the 'conditions' in which they lived); but the Board was able to draw on its network of honorary guardians over a much longer period. In their first couple of months they issued

a circular letter to the several honorary correspondents, wardens, police
magistrates and respectable settlers throughout the Colony, asking
information as to the numbers, condition and location of the Aborigines
$\ldots$ This letter was published in the newspapers; it attained a wide
circulation and the attention of all classes was directed to it ... a mass of
information was collected which has been of great utility to the Board. ${ }^{94}$

Soon, this information would be supported by regular inspections by the two employees of the Board, guardian William Thomas and secretary Brough Smyth.

93 CBPA, 'Minutes of meetings', NAA, Series B314, May 1864.

94 Second CBPA Annual Report (1862): 6. 
Indeed, Brough Smyth's near-maniacal activities in the early 1860s crafted a geography of Aboriginal life through which the governance of Aboriginal people would unfold.

Whilst the early reports of the CBPA both recounted a litany of impoverishment and functioned as a sorry indictment of colonial indifference, soon, a sense of muted optimism shaped the discussion of the emerging system of reserves, missions and rations. Of course the condemnation of colonial treatment and the muted celebration of CBPA success must be read, at least in part, as a justification of expenditure. However, a firm rejection of inevitable extinction began to emerge. Soon after the replacement of Heales as chair, and drawing upon the geography of Aboriginal life crafted by Brough Smyth, the Board began to argue firmly against the notion of Indigenous disappearance. In his first report as President of the CBPA in 1865, James MacBain argued that 'there is hope this people may yet be preserved' not only from the 'harsher miseries' of colonial dispossession but disappearance altogether. ${ }^{95}$ Drawing on accounts of the Boardmanaged station at Coranderrk in particular, the CBPA provided evidence of declining mortality rates. The blunt fact of Aboriginal survival functioned as a powerful disruption to the powerful narrative of extinction (which for the Board was a sign of their success rather than the agency of Aboriginal communities adapting to the harsh realities of colonial life). There was 'no reason to believe that there has been any great decrease in the numbers of Aborigines in the past few years [and] the Board does not hesitate to declare that the often repeated statement that the race is disappearing is by no means in accordance with fact ${ }^{\prime}{ }^{96}$

Indeed, the Board mobilised this kind of thinking in spite of the evidence that many of its correspondents provided. Whilst evangelical zeal meant the missionaries could employ spiritual instruction as a signifier of success, local guardians who both distributed rations to those outside the reserve system and offered judgements about its success still tended to stubbornly mobilise notions of decline and disappearance. These correspondents, the Board noted, did not 'entertain any hope of their condition being greatly ameliorated'. These honorary gaurdians from the edges of the colony argued 'they still roam from place to place, frequent towns and goldfields where possible and remain sometimes for months out of the control of the Board' ${ }^{97}$ Few could imagine a colonial future in which Aboriginal people could carve out an existence in the colonies, and it was only through the actions of the Board that they could avoid complete destitution in the present. The Board received a litany of correspondence in which settlers still asserted 'they are rapidly disappearing', ${ }^{98}$ they were about to

95 Fourth CBPA Annual Report (1864): 8.

96 Ninth CBPA Annual Report (1873): 4.

97 Second CBPA Annual Report (1862): 8.

98 First CBPA Annual Report (1861): 22. 
'become extinct', and that no amount of 'moral and social' improvement could alter the fact that their 'indolence and carelessness' meant they were 'destined' for 'extinction'. ${ }^{99}$ According to the narratives of Presbyterians like MacBain, however, the system of reserves and stations firmly demonstrated the folly of this kind of thinking. Holding up Coranderrk as the example of success, this 'prove[d] that the Aborigines living on these stations are not only civilized but equal to the performance of duties that civilization imposes'.$^{100}$

The Board, then, had slowly adopted the strand of thinking that had shaped Presbyterian missionary support for the actions of Moravians in the 1850s. Material and spiritual action in the present might produce an earthly future. It cannot be a coincidence that after the death of Richard Heales, the Board was dominated by its agnostic secretary Brough Smyth, the Methodist Theo Sumner, the Presbyterian James MacBain, and was deeply indebted to the hard work of MacBain's friend and former employee the staunch Presbyterian John Mackenzie. (Mackenzie's own experiences of migration and hard work had elevated him from the life of a 'shephard' in Scotland to a landholder in Victoria; in some ways his own life resonated with the reforming project of the Board.) This was not, however, a straightforward mobilisation of the narratives of Christian reform and reclamation that characterised the 1850s network of Presbyterian support for evangelical action. There were subtle, but nonetheless important, shifts in ideas about the practices and actions that would underpin these humanitarian engagements. The different kinds of discursive work that the notion 'reclamation' would perform over the years between 1850 and 1870 exemplify these subtle but important differences in amplification.

Like so many other agents in the 'empire of religion' that Hilary Carey has so carefully traced, the missionary endeavour in colonial Victoria was determined to 'reclaim fallen' peoples - and, moreover, this practice granted empire moral legitimacy because it made imperialism the mechanism for evangelism. ${ }^{101}$ As Porter argues, theological changes of the eighteenth century had recast Indigenous peoples as victims, not only of imperial violence and mistreatment, but also of their earthly location outside of God's empire. The promise of missionary work for Protestant faiths was 'that conversion of the world would usher in the millennium of peace, happiness and plenty, at the end of which Christ would return to earth'. The impacts of these theological transformations were, of course, socially and culturally uneven. However, they did encourage 'evangelism on the widest possible front' because it became possible to restore so-called savages to the grace of the gospel rather than assume their spiritual

99 Third CBPA Annual Report (1864): 8; see also CBPA, 'Minutes of meetings', NAA, Series B314, May 1861-62.

100 Ninth BPA Annual Report (1873): 3.

101 Carey, God's Empire: 23. 
fate was sealed. ${ }^{102}$ The evangelical revival that followed, as Anna Johnson points out, was energised by a belief that everyday people (whether the poor in Britain or Indigenous peoples in the imperial periphery) had first 'fallen' from grace and thus could be 'restored'. ${ }^{103}$ In evangelical terms, Aboriginal people in Victoria were thus understood as 'a degraded [people to be] brought to the knowledge of Christ'. They could, through missionary action, be 'reclaimed' to and by Christ. ${ }^{104}$ As evangelicals sought support in the 1850s they recounted stories of missionary success from other colonies; a meeting of the board of the Anglican Mission in Victoria was encouraged by 'success ... at Port Lincoln [which] proved there was no ground for the despair that some people indulged in as to the reclamation of the Aborigines' ${ }^{105}$

However, in the 1860s the notion of reclamation would be put to work to describe a process of a rather more secular character. A Victorian Presbyterian minister in 1864 argued that his fellow colonists could 'reclaim the aborigines from their primeval savagery' by teaching them the 'habits of civilisation'. ${ }^{106}$ So too, The Argus suggested that to 'reclaim the aboriginal races from indolence' might be the only possible way to 'save them from extinction' ${ }^{107}$ A year later it noted that if Aboriginal people were allowed to 'grow up wild and no effort [was] made to reclaim them ... [they would] fast die away', although humanitarian action was no guarantee of its success. ${ }^{108}$ Even the most pessimistic accounts about Aboriginal futures adopted the narrative of reclamation - if only to suggest its impossibility. The Ballarat Star reported on 'their [slow] progress in civilisation' to argue that even 'the most favourable circumstances show no better results. [It is] futile to attempt to reclaim the mature savage'. ${ }^{109}$ Settlers who took the Board's predictions of an Aboriginal future seriously suggested that actions of a 'very patient and zealous teacher might amend their condition and gradually indoctrinate their minds with rudimentary notions of industry and progress'; through this kind of activity they could be 'reclaimed and brought round to civilized habits'. ${ }^{110}$ For some settlers, whilst the system of reserves and compulsion the Board sought could be 'open to some objections [since] it interferes with the liberty of the subject - or rather savage ... no such objection exists here'. In this mode of thought, the 'government ... should lend itself to reclaim the natives'. ${ }^{111}$

\footnotetext{
102 Andrew Porter, 'An overview, 1700-1914', in Missions and Empire, Norman Etherington (ed): 55.

103 Johnson, Missionary Writing and Empire, 1800-1860: 23.

104 Further Facts Relating to the Moravian Mission (1863): 2.

105 Ballarat Star, 4 July 1859: 3.

106 Brisbane Courier, 22 January 1864: 5.

107 The Argus, 12 December 1860: 5.

108 The Argus, 16 September 1861: 8

109 Ballarat Star, 30 December 1862: 2.

110 Sydney Morning Herald, 7 June 1866: 2.

111 Rodney Advertiser (Heathcote), 25 September 1868: 4.
} 
This was not simply paternalism, or the combination of 'Civilization and Christianization', but the adoption of an evangelical vocabulary to describe a social and possibly historical transformation. The Board, figures like Brough Smyth and James MacBain argued, could 'reclaim the black to civilisation', where that reclamation was carefully distinguished from the 'religious instruction of the natives'. ${ }^{112}$ Nourished by the Presbyterian faith that reclamation could reverse the trajectory towards extinction, this kind of thinking easily reworked this notion of religious reclamation into a near ethnographic claim about reclamation to the 'habits of civilisation', if not shucked its spiritual consequences off altogether. Indeed, in 1869 the CBPA asserted that

the most prosperous Aboriginal station in Victoria, or perhaps in Australia, has been exclusively managed by the Board and its officers with no extraneous [religious] assistance ... the complete revolution in the lives and habits ... have far exceeded the most sanguine expectations of the Board who have had the largest experience of the Aboriginal character. ${ }^{113}$

\section{A vernacular ethnography}

A crucial element of this shift in thinking (and the possibility of reclamation within it) was the development of a vernacular ethnography in both colonial public life in the 1850s and 1860s and the activities of the Board after its first meeting. Whilst missionaries had certainly pondered the spiritual and social 'character' of their charges and were often crucial translators of Aboriginal language and social practice, evangelical engagements with difference did not have nearly the same kind of discursive purchase (nor widespread intellectual activity) that an emerging network of amateur ethnographers and ethnologists would soon assume in the colony. Moreover, the production of these vernacular ethnographies was sustained by a steady murmur of interest in public life. Nourished by the intellectual activities of metropolitan institutions like the British Association for the Advacement of Science, the Social Science Association and the emerging (and constantly splitting) Ethnological and Anthropological societies in London, a network of colonial ethnographers began to seriously ponder the various ways in which they could understand the difference between Aboriginal people and the settlers who were responsible for their 'care and management'. In the 1850s the colony abounded with ethnographic lectures, displays of Aboriginal artefacts (and bodies), performances of Aboriginal ceremonies, and - perhaps most importantly - a steady population of middle-

112 Ninth BPA Annual Report (1873): 6.

113 Sixth CBPA Annual Report (1869): 34. 
class men who claimed expertise. ${ }^{114}$ Using their early experiences of the colony or their efforts to collect 'facts' about the remaining Aboriginal population, these men claimed status in colonial intellectual and scientific life. As others in this collection have noted, the work of William Thomas in the 1850s was a crucial example of this kind of enquiry. However, Thomas's work was nourished by the activities of a much wider network of amateur ethnographers (whose interests often moved between natural history, geology and other sciences of man and nature in the years when the divisions between these branches of knowledge and enquiry were ill-formed at best); these men were deeply engaged with the metropolitan debates about human difference and adapted and adopted these discursive frames to ponder the substance of racial difference. Victorian colonists, they often claimed, needed to investigate the character, temperament and capacity of Aboriginal people.

The parliamentary and bureaucratic practices that authored the governance of Aboriginal people in the late 1850s and 1860s were deeply entangled with this project of ethnographic investigation. McCombie's Select Committee in 1858 was as much directed by ethnographic enquiry as it was by humanitarian intervention. Making use of the extensive ethnographic questionnaire developed by the Aborigines Protection Society and the British Association for the Advacement of Science in Britain in the 1840s, the committee asked all its respondents and witnesses to provide information about the beliefs, language, social practices and bodies of Aboriginal people. McCombie had, in fact, published this survey in the Port Phillip Gazette in the late 1840s, but as chair of the select committee he could draw on parliamentary authority to produce the kind of information he sought. Over two thirds of the information collected by the select committee concerned ethnographically imagined character rather than the destructions of colonialism. (Moreover, like the inchoate development of anthropology unfolding at this time, there was little consonance in the differences these observers discovered.) The time had come, McCombie long asserted, to see if the 'Aborigine was fit for a political existence' and ethnographic enquiry would provide the answer. ${ }^{115}$ Others agreed, noting that 'some singular ethnological facts may [produce] a better knowledge of our blacks [and] lead to their elevation in the social scale. If neither their morals nor their intellects can be improved, their physical condition may, at any rate, be ameliorated.' ${ }^{116}$

The connection between governance and ethnography did not, however, stop with McCombie. The Board itself became an avenue of ethnographic enquiry whilst the Board acknowledged that their remit was limited to the 'amelioration of the blacks' they nonetheless supported the voracious ethnographic activities

114 The Argus, 3 January 1856: 5.

115 Report of the Select Committee of the Legislative Council on the Aborigines (1859): vii.

116 The Argus, 13 September 1860: 4. 
of their secretary, Brough Smyth (in sharp contrast to their refusal of support for missionary endeavours). In the 1870s he would publish his work on the Aborigines of Victoria; in the 1860s he had used the Board and its network as a crucial mechanism to conduct his enquiries. Indeed, this work was originally commissioned by the Board in 1865 when the members acknowledged they could hardly expect to govern Aboriginal futures if they did not understand Aboriginal people. In his first report as president, MacBain acknowledged that 'though not properly within their functions' they could see the value of Brough Smyth's enquiries. MacBain wrote that 'the Board have encouraged the secretary in prosecuting this work, as the means of collecting information at their command'. ${ }^{117}$ The Board, then, did not simply support this enquiry - it was also its agent. By 1866, its ethnographic collection was substantive enough to 'exhibit a very large assortment of native weapons, and also specimens of baskets, bags, nets, bonnets, pincushions, \&c, the work of native hands' ${ }^{118}$ The network of honorary corrospondents, many of whom fancied themselves as ethnographic experts, had donated their own collections of 'weapons and utensils'. ${ }^{119}$ As Samuel Furphy has noted, these objects became both a performance of difference and a demonstration of capacity, as goods destined for European consumption were displayed as evidence of the possibility of Aboriginal adaptation for a colonial future. ${ }^{120}$

Of course, there were important differences between the vocabularies through which evangelicals understood Aboriginal people and the project of ethnography. However, many of the practices they sustained were remarkably similar (the collection of language and social practices) and some colonists moved across and between these networks and the divergent vocabularies they produced. ${ }^{121}$ The development of a vernacular ethnography allowed colonists to draw much stronger distinctions between Europeans and their colonised subjects than the universalising vocabularies of evangelical practice. Humanitarian compassion as it took shape in the early nineteenth century often employed notions of the 'family of man' and its 'brotherhood' to offer criticism of the treatment of both slaves and then Indigenous peoples. Missionaries and church leaders in Victoria in the 1850s agreed, Aboriginal people and colonists were part of 'one great family of mankind' the missionary Spieseke argued. ${ }^{122}$ So too, the Bishop of Melbourne reminded the colonists that Aboriginal people were 'his fellow creatures, his fellow subjects, and his fellow inhabitants of the same land as

\footnotetext{
117 Fifth CBPA Annual Report (1866): 10.

118 The Argus, 25 October 1866: 5-7.

119 Second CBPA Annual Report (1862): 14.

120 See chapter 4 in this collection.

121 This should be no surprise, the men who spearheaded the British APS in the 1840s were the same figures who developed the BAAS survey in the same decade - these discursive distinctions emerged inchoately and untidily.

122 First CBPA Annual Report (1861): 22.
} 
himself' ${ }^{123}$ They were all God's children and this familial connection produced obligations of care and protection. In contrast, these ethnographers produced a powerful language of difference that could legitimate distinct practices of governance (regardless of where they imaginatively located the source of this difference, or whether they thought it was intransigent, could be changed in individual Aboriginal people or transformed through generational change over time). The Aboriginal people who had been the object of evangelical compassion became, through this ethnographic vocabulary, a governable Aboriginal subject. Moreover, this negotiated another powerful contradiction of British settler colonialism, the distinction between the ostensibly undifferentiated rights of British subjecthood and the blunt inequalities of colonial rule.

\section{Conclusion}

What I have tried to suggest in this chapter, then, is that Aboriginal people became governable subjects in colonial Victoria through a set of subtle but important adjustments to extant evangelical vocabularies. The notion of 'protection', long understood to represent the compassionate amelioration of the destructions of settlers, was adopted and reworked by the Board into a strategy of liberal governance. In the context of a colonial state still assembling the mechanisms through which it would organise civil society, the market and private life (and the boundaries that would limit its intervention into those realms), the CBPA deployed a developing vernacular ethnography to justify arranging those limits and boundaries in quite different ways. This was, then, more than state support for missionary activity under the guise of Christianisation and Civilisation the Board drew upon, reworked and sometimes contested evangelical ideas about human difference, reclamation and the dying race to legitimate a form of governance with almost unprecedented reach into Aboriginal lives. The ways in which the Board remained attached to narratives of individual reclamation - even when that process had been shucked of its spiritual dimensions demonstrates the ways in which extant stories and practices could easily be reworked for more earthly consequence.

We need, I suspect, much more careful accounts of the ways in which denominational differences opened out different meanings of 'protection' and the ways in which these differences shaped how liberal governance would unfold. Evangelical practices and ideas clearly become a vehicle for working through liberal modernity in its settler colonial inflection. Elizabeth Elbourne suggests that around the middle of the nineteenth century, 'liberalism resolved the paradox of colonialism' by creating a grammar of racial difference through

123 The Argus, 17 January 1857: 4. 
which certain subjects could have their rights suspended. For Elbourne, the universalising claims of humanitarianism could never quite 'fit' with the blunt territorial imperatives of settler colonialism. ${ }^{124}$ That is certainly part of this picture, however, a rigid division between the political and the religious loses sight of the ways in which certain forms of religious belief and practice could become vehicles of liberal modernity. It cannot be a coincidence that these transformations unfolded as the Board came to be dominated by Presbyterians in the middle of the 1860s - indeed, the glimmers of many of these changes were beginning to emerge in Presbyterian thinking in Victoria in the 1850s. This, perhaps, should not be a surprise. The long history of free thought and dissent meant 'liberal impulses' could find an easy home within Presbyterian practice. ${ }^{125}$ As one Victorian Presbyterian noted, a congregation characterised by 'freedom of thought and action' was an 'honour to the denomination'. ${ }^{126}$ Presbyterian notions of individual reform as a spiritual work unfolding over a lifetime could be easily mapped onto projects of social reform and the improvement of others. Richard Sher's now all-too-familiar argument that moderate Presbyterians were key carriers of the Enlightenment project in Scotland would seem to have as yet unexplored colonial resonances. This might also explain why so many architects of the colonial state in Victoria were Scots radicals. ${ }^{127}$

These changes were not, however, simply the transformation of ideas. They had significant consequences for Aboriginal people. There is no question that this piece of legislation imagined and legitimated a regime of control and management that would continue the project of dispossession (by removing Aboriginal people from settler space). At the same time, this vernacular ethnography effectively short-circuited the languages of shared humanity that structured evangelical practice. Indeed, in the 1860s the CBPA materially reproduced its ideas about ethnographic specificity by ensuring as many Aboriginal people as possible were dressed in clothing with the 'same peculiar pattern' ${ }^{128}$ These were not people imagined to be individual liberal subjects.

\footnotetext{
124 Elbourne, 'The sin of the settler'.

125 AR Holmes, 'Covenanter politics: evangelicalism, political liberalism and Ulster Presbyterians, 17981914', English Historical Review 125(513), 2010: 340-369. Reformist and radical liberal thinking, much of which was united by a sense of historical progress, 'was underpinned to a large extent by Presbyterian ecclesiology ... Many Scots Presbyterians expressed their dissatisfaction with an unreformed British government which failed to accord with Presbyterian principles. A desire to protect the independence of the Church of Scotland and an ideological objection to the position of bishops in the House of Lords - that is, the intermingling of the spiritual and temporal spheres - inspired reformist protests and democratic tendencies'. Valerie Wallace, 'Benthamite radicalism and its Scots Presbyterian contexts', Utilitas 24(01), 2012: 7.

126 A letter to the Mission Board on the United Presbyterian Church of Scotland ... concerning the Geelong Congregation, Thomas Patterson, Geelong, 1858: 2.

127 Richard Sher, The Enlightenment and the Book: Scottish Authors and Their Publishers in EighteenthCentury Britain, Ireland, and America, University of Chicago Press, Chicago and London, 2006.

128 The Argus, 25 June 1864: 8.
} 
The question remains, however, whether the 1869 Protection Act energised a grammar of racial difference of a kind that that historians of race would comfortably identify 'qua' race. Historians of empire suggest that racial categories hardened somewhere around the mid century; this 'hardening' usually represents a loss of particular modes of relating to non-Europeans that, in turn, made violent repression more palatable. ${ }^{129}$ This seems a strange narrative when the history of settler colonialism is considered - relationships between settlers and Indigenous peoples tended to become less rather than more violent as the century unfolded, closer rather than more distant. Clearly, however, midcentury understandings of human difference did not have the kind of biological instrumentalism ('hardness') that produced the possibility of 'breeding out the colour' half a century later. Perhaps for this reason, scholars often shy away from seeing race as an operative category in the 1869 Act. ${ }^{130}$ However, just because the apparent differences between Aborigines and Europeans did not have the imagined immutability that we might recognise as 'race' does not mean that they were operatively insignificant. The explosion of what was termed either ethnological or anthropological inquiry in the 1850s and 1860s in Victoria suggests that grammars of difference were being elaborated that had some degree of purchase. Whilst colonists might have disagreed about the precise texture of these differences (and whether or not they would be historically stable) they nonetheless legitimated the possibility of different forms of rule.

The actions and practices of the subjects imagined by this form of governance were, however, unpredictable. The formalisation of the reserve system clearly offered communities moments of respite through which to adopt and adapt to their transformed worlds. So too, many Aboriginal people refused to mirror the Board's desires for a contained and disciplined population within that system. Even after the legislation, people moved on and off the reserve system and the Board struggled to enforce the kinds of limitations this legislation invoked. Moreover, soon Aboriginal people began to mobilise the notion of exceptional subjecthood in the 1870s to contest the actions and management of the BPA itself. The brief and fragile assemblage of ideas and practices that produced the 1869 Act began to transform almost as soon as the final vote was cast in colonial parliament.

129 See, for example, Catherine Hall, 'The economy of intellectual prestige: Thomas Carlyle, John Stuart Mill, and the case of Governor Eyre', Cultural Critique 12, 1989: 167-196.

130 See, for example, John McCorquodale, 'The legal classification of race in Australia', Aboriginal History 10(1), 1986: 7. 
This text is taken from Settler Colonial Governance in Nineteenth-Century Victoria, edited by Leigh Boucher and Lynette Russell, published 2015 by ANU Press and Aboriginal History Inc., The Australian National University, Canberra, Australia. 